\title{
Marginal bone loss in dental implants: factors affecting and how to prevent it
}

Dental implantology is today a science based and grounded in the scientific evidence provided by the numerous studies (mainly randomized clinical trials and meta-analysis) that have been carried out in recent decades. This scientific basis provides a detailed knowledge of the biological and clinical processes that affect each and every one of the steps related to implantsupported rehabilitation. Since Albrektsson, absolute contraindications have been moderating in implantology, leaving some of them as the limitations of hard and soft tissue, relegated to relative contraindications and manageable by dentists specializing in implantology, using bone and tissue regenerative techniques. The number of implants currently placed in the world is very high and this has brought about effects and complications that have been increasing in recent years, mainly marginal bone loss (MBL) and peri-implant diseases (mainly peri-implantitis). It is in these fields where the scientific evidence is most limited and many of the aspects and associated factors need to be clarified.

This special series "Marginal bone loss in dental implants: factors that affect and how to prevent it" intends, through expert and consolidated authors and scientists in the area, to shed more light on the aspects related to MBL. The effect of implant loading, immediate or delayed implant placement after sinus lift, the use of photobiomodulation, as well as the role of abutments in MBL, will be discussed in the following issues.

\section{Acknowledgments}

Funding: None.

\section{Footnote}

Provenance and Peer Review: This article was commissioned by the editorial office, Frontiers of Oral and Maxillofacial Medicine for the series "Marginal Bone Loss in Dental Implants: Factors Affecting and How to Prevent It". The article did not undergo external peer review.

Conflicts of Interest: The author has completed the ICMJE uniform disclosure form (https://fomm.amegroups.com/article/ view/10.21037/fomm-21-105/coif). The series "Marginal Bone Loss in Dental Implants: Factors Affecting and How to Prevent It" was commissioned by the editorial office without any funding or sponsorship. MPS served as the unpaid guest editor of the series and serves as an unpaid editorial board member of Frontiers of Oral and Maxillofacial Medicine. MPS receives consulting fees from AMCA. The author has no other conflicts of interest to declare.

Ethical Statement: The author is accountable for all aspects of the work in ensuring that questions related to the accuracy or integrity of any part of the work are appropriately investigated and resolved.

Open Access Statement: This is an Open Access article distributed in accordance with the Creative Commons AttributionNonCommercial-NoDerivs 4.0 International License (CC BY-NC-ND 4.0), which permits the non-commercial replication and distribution of the article with the strict proviso that no changes or edits are made and the original work is properly cited (including links to both the formal publication through the relevant DOI and the license). See: https://creativecommons.org/ licenses/by-nc-nd/4.0/. 
Mario Pérez-Sayáns, PhD, MDS, FDS, DDS

Oral Medicine, Oral Surgery and Implantology Unit, Faculty of Medicine and Dentistry, Santiago de Compostela, Spain.

(Email:mario.perez@usc.es)

Received: 19 October 2021; Accepted: 06 December 2021; Published: 10 March 2022.

doi: $10.21037 /$ fomm-21-105

View this article at: http://dx.doi.org/10.21037/fomm-21-105

doi: $10.21037 /$ fomm-21-105

Cite this article as: Pérez-Sayáns M. Marginal bone loss in dental implants: factors affecting and how to prevent it. Front Oral Maxillofac Med 2022;4:10. 